\title{
床振動に対する振動感覚，不快度評価に関する実験的研究 その 1 継続時間のもたらす影響 \\ EXPERIMENTAL STUDY ON HUMAN SENSITIVITY AND DISCOMFORT TO FLOOR VIBRATION (PART 1)
}

\author{
高橋良典 ${ }^{* 1}$, 吉岡宏和 ${ }^{* 1}$, 井上竜太 ${ }^{* 2}$, 田中利幸*3 \\ Yoshinori TAKAHASHI, Hirokazu YOSHIOKA, Ryuta INOUE \\ and Toshiyuki TANAKA
}

\begin{abstract}
This paper discussed on human sensitivity and discomfort to floor vibrations with various duration times. Shaking table tests with vibrations of various combinations of the frequencies, amplitudes and duration times were performed. The sensitivity and the discomfort to the whole-body vibrations are evaluated by test subjects seated on the shaking table.

As the results, the duration times influence to the discomfort more than the sensitivity to the vibrations. The discomfort to the vibration with the duration time of $30 \mathrm{sec}$. increases about from 1.2 to 1.3 times as large as one with the duration time of $3 \mathrm{sec}$.
\end{abstract}

Keywords : Floor vibration, Sensitivity to vibration, Discomfort, Duration time of vibration 床振動，振動感覚，不快度，床振動の継続時間

\section{1. はじめに}

床構造は、人、家具、機器等の荷重を支える役割を果たすと共に、それ らの人為的、機械的加振を直接受け吸収する役割を果たしており、室 内睘境にとって重要な位置付けにある。

鉄骨造大スパン床構造の振動実験結果から得られる减衰定数は、1〜 $2 \%$ 程度の低い値を示すことが多く、減衰定数の低さは、正弦波加振で は『著しい共振現象』を、周期的な衙撃加振に対しては『振動の重複・ 增幅（共振）現象』を引き起こし、これらが振動障害として現れる例 は少なくない。筆者らは、床構造体の持つ隇衰性能の差異が、林構造体 の振動性状にどの様な変化を与え、人間の感覚にどの様な影響をもた らすかを実験結果に基づき定量的に示すと共に、歩行、小走り等の日 常的な外乱に対する動吸振器による床振動制御法の有効性を既報に おいて報告した。 ${ }^{1) 31}$

こうした研究を進め実建物に適用する中で、継続時間 10〜30 秒、最 大振幅 3 $5 \mathrm{~cm} / \mathrm{sec}^{2}$ 程度の床振動が不規則かつ断続的に綝り返し発生 するクレーム事例に遭遇した。この事例では、クレームが発生した 1993 年当時、事務所における床振動の許容レベルと考えられていた $5 \mathrm{~cm} / \mathrm{sec}^{2}$ 程度の床振動が生じた場合に、事務所内で執務する人々の大 半が、業務上不快と訴える状態であり、事務所における床振動の許容 レベルを見直す必要が生じた。

クレームの主要因は床振動の継続時間と考えられたが、当時参照可 能な既往の研究 ${ }^{4}$ は、振動を感じる人の知覚、感覚的な大きさに注月
したものが大半で、振動を感じる人の不快感に注目したものが無かっ

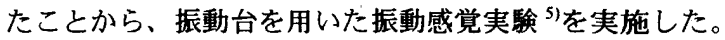

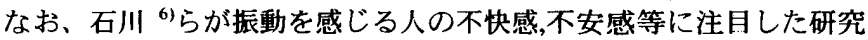
を行なっているが、現在も、本論文が対象とした継続時間の振動を取 り扱った研究事例は数少ない。

本振動感覚実験の概要,結果を要約し、以下に記述する。

\section{2. 実釦の概要}

クレーム事例を参考に、図 1 ,表 1 に示すようにモデル化した刺激振動 を振動台上で再現し、評価実験を行なうことによって、振動の大きさ、 継続時間、種類と振動感覚評価、不快度評価の関係を検討した。本実験 に用いる振動波形（刺激）の特徵は、以下に記述する通りである。

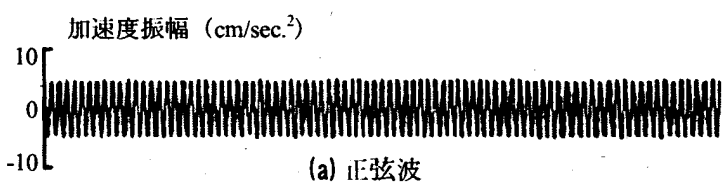

(a) IE弦波

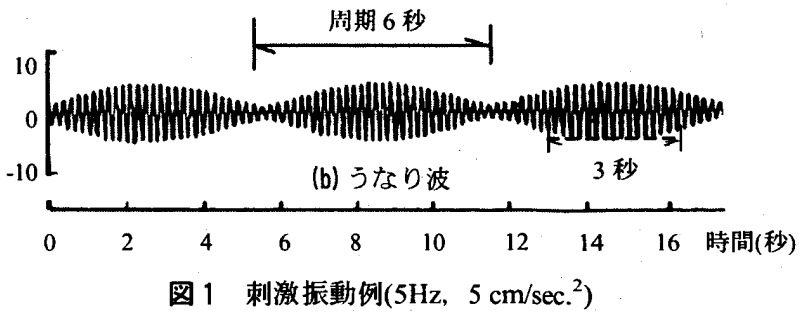

*1 竹中工務店 技術研究所 主任研究員 - 博士 (工学)

*2 竹中工務店 技術研究所 研究員・博士 (工学)

*3 竹中工務店 大阪本店. 営業部 副部長. 工博
Chief Researcher, R\&D Institute, Takenaka Corp., Dr. Eng.

Researcher, R\&D Institute, Takenaka Corp., Dr. Eng.

Senior Manager, Business Promotion Dept., Osaka Main Office, Takenaka Corp., Dr. Eng. 
・図 1 に見られるように、 $2.5 \mathrm{~Hz}$ の周期的な衝撃加振によって、 $5 \mathrm{~Hz}$ 、 $7.5 \mathrm{~Hz}$ の固有振動数を持つ床が共振し、一定振幅の正弦波、または 6 秒周期でうなり波を生じる状態を想定している。

・最大振幅は、クレーム発生時に活用されていた日本建築学会『建築 物の振動に関する居住性能評価指針・同解説（制定 1991）』（以 下学会旧指針(1991) と記す。)の連続振動に対する性能評価区分、 ランクを参考に、 $5 \mathrm{~cm} / \mathrm{sec}^{2}$ (V-5 : 事務所の一般的なよりどころ)、 $3 \mathrm{~cm} / \mathrm{sec}^{2}{ }^{2}\left(\mathrm{~V}-3\right.$ : 事務所のより望ましいレベル)、 $1.5 \mathrm{~cm} / \mathrm{sec}^{2}{ }^{2}(\mathrm{~V}-1.5:$ 会 議・匛接室のより望ましいレベル)の 3 段階に、 $2 \mathrm{~cm} / \mathrm{sec}^{2} 、 2.5 \mathrm{~cm} / \mathrm{sec}^{2}{ }^{2}$ を加えた 5 段階の目標振幅を設定している。

・継続時間については、日常的に体感する振動としては、比較的継続 時間の長い 10〜30 秒の振動と、歩行振動などの継続時間の短い休 振動との相違が検討できるように、 3 秒、 5 秒、10 秒と 30 秒の 4 つ の継続時間を設定した。

表 1 刺激振動の一覧 $(5 \mathrm{~Hz}, 7.5 \mathrm{~Hz})$

\begin{tabular}{|c|c|c|c|c|c|c|}
\hline \multirow{2}{*}{$\begin{array}{l}\text { 波の } \\
\text { 種類 }\end{array}$} & \multirow{2}{*}{$\begin{array}{c}\text { 継続時間 } \\
\text { (秒) }\end{array}$} & \multicolumn{5}{|c|}{ 月標最大加速度 $(\mathrm{cm} / \mathrm{s} 2)$} \\
\hline & & 1.5 & 2.0 & 2.5 & 3.0 & 5.0 \\
\hline \multirow{4}{*}{ 正弦波 } & 3 & - & 0 & - & 0 & 0 \\
\hline & 5 & - & 0 & - & 0 & 0 \\
\hline & 10 & 0 & 0 & 0 & 0 & 0 \\
\hline & 30 & 0 & 0 & 0 & 0 & 0 \\
\hline うなり波 & 30 & 0 & 0 & 0 & 0 & 0 \\
\hline
\end{tabular}

○: 実呀を実施した刺激 一 : 実験を実施しなかった刺激

図 2 に振動感覚実験のブロックダイアグラムを示す。図に示すよう に計算機内部に記憶させた波形データは、 D/A コンバーターを介して 振動台に入力される。また、振動台テーブル中央位置にセットした振 動センサから得られた加速度波形を分析し、加振時間内の最大振動レ ベル9゙をコンピューターに転送し記録する。

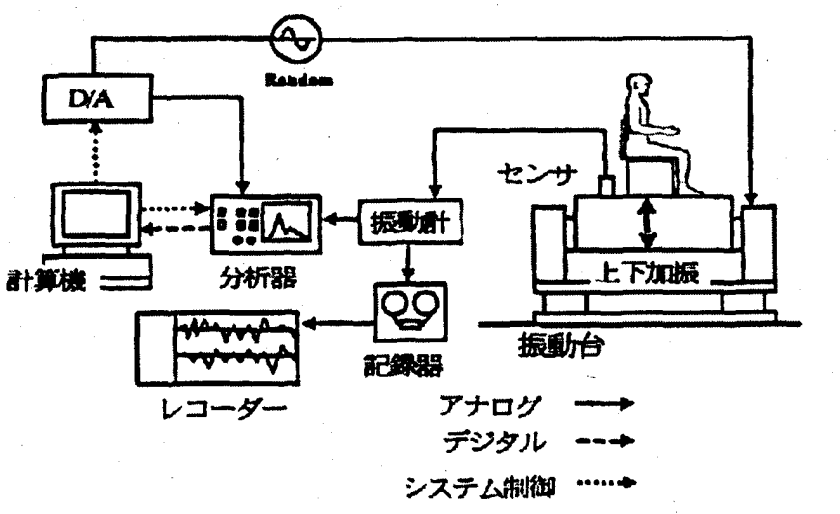

図 2 実験計測のブロックダイアグラム

振動レベルは、JIS C 1510 に定められた人間の振動感覚特性を考虑し た加速度のパワー（実効值）を対数表現したものである。

$$
\mathrm{VL}(\text { 振動レベル } \mathrm{dB})=10 \log \left(\mathrm{A} / \mathrm{A}_{0}\right)^{2} \ldots . . .(1)
$$

$\mathrm{A}$ : 加速度振幅 $\left(\mathrm{cm} / \mathrm{sec}^{2}\right.$ 実効值)

$\mathrm{A}_{0}$ ：基準加速度振幅 $=10^{-3}\left(\mathrm{~cm} / \mathrm{sec}^{2}\right.$ 実効値 $)$

本実験のように非常に微小な振動を対象とする場合、振動台稼動時 の微動(ノイズ)の影響を含めた振幅を正当に評価する必要がある。

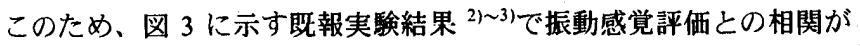
明らかとなった(2)式を介して算出される換算加速度 $\mathrm{A}_{\mathrm{eq}}$ を各刺激振動 の最大加速度とした。(以下 $\mathrm{A}_{\mathrm{eq}}$ を最大加速度と記する。)
$\mathrm{A}_{\mathrm{eq}}=10^{(\mathrm{L}-60) / 20} \times \alpha$

$\mathrm{A}_{\mathrm{eq}}$ : 換算加速度 $\left(\mathrm{cm} / \mathrm{sec}^{2}\right.$ 0-P 值），L：振動 $\wedge^{*} 川(\mathrm{~dB})$ $\alpha:=\sqrt{2}$ (実効值から 0-P 值への変換係数)

共振 1 人

(加振比将 $2.0 \mathrm{~Hz}$

非共振 1 人

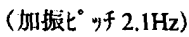

共振 1 人

(加振

非共振 1 人

(加拢 ビ 米 $2.1 \mathrm{~Hz}$ )

衙慗加振

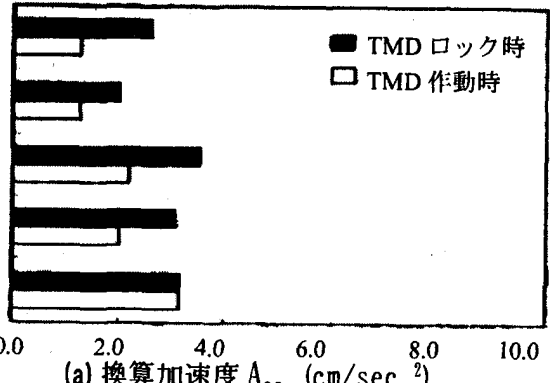

(a) 換算加速度 $A_{\mathrm{eq}}\left(\mathrm{cm} / \mathrm{sec}^{2}{ }^{2}\right)$

共振 1 人

(加振比 斗 $2.0 \mathrm{~Hz}$ )

非具报 1 人

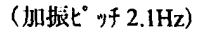

其振 1 人

(师振ピ゙ ッ $2.0 \mathrm{~Hz})$

非其振 1 人

(加振ピ・゙ $2.1 \mathrm{~Hz}$ )

衙慗加振

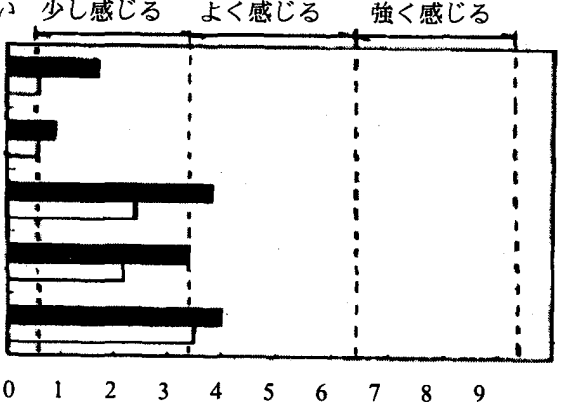

(b) 振動感覚評価

図 3 振動い゙ ルから算出される換算加速度と振動感覚評価の関俰 ${ }^{31}$

写真 1 に示すように、被験者は振動台中央部に 1 人ずつ座り、各振動 数に分けランダムに配置された 21 種類の刺激振動を各々 2 回ずつ与 えられ、評価シートに振動感覚評価、不快度評価を記入する。

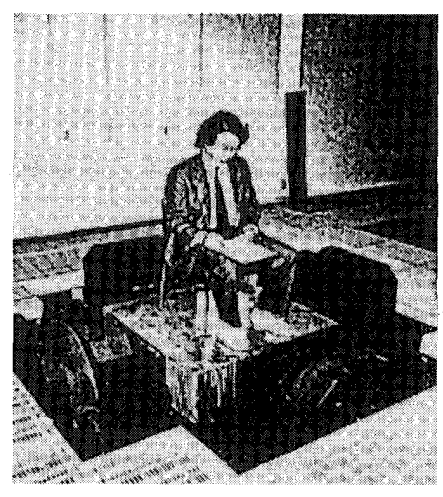

写真 1 振動感覚契験の状況

実験に使用した振動台は動電型のもので、最大加振力 $12,000 \mathrm{kN}$ 、振動 台テーブル寸法 $1,000 \times 1,000 \mathrm{~mm}$ 、可動部重量 $500 \mathrm{~kg}$ が主な仕様である。 振動台のもつ常時微動は、主に油圧ユニットから発生するもので加速 度振蝠 $0.5 \mathrm{~cm} / \mathrm{sec}^{2}$ 以下（振動レベル $40 \mathrm{~dB}$ 以下）であった。

また、椅子と振動台は固定していないが、予備試験によって振動台上 から椅子座面（底板）への振動增幅、振動台および椅子座面の水平振 動量をチェックており、振動台上から椅子座面への振動增幅は、水平. 上下共に振動げル差で+0.5dB（+5\%）以下、振動台および椅子座面の

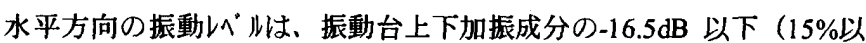
下）であった。この予備試験結果をもとにクレームが起きた睟境の再現を 重視して、床振動を評価する対象として振動台上の加速度を採用した。 表 2 に示すように、健康な成人(男子 24 名、女子 9 名、年歯 20～50才) 合計 33 名を被験者とした。実験時における被験者の姿勢は事務用イ スに座る姿勢であり、クッションに類するものは用いていない。 
なお、実験は長時間にわたるために、振動数毎に実施しており、1つの 振動数、1 人当りの実験時間は $20 \sim 25$ 分程度である。

なお、振動感覚評価については、感覚的な大きさに注目した”感じな い”，”少し感じる”，"よく感じる”と”強く感じる”の 4 段階の評 価区分を用いた。

また、不快度評価としては、被験者が事務スペース内で業務中に受け る振動としての不快度に注目し、”不快である”，息ちらとも言えな い”と”不快でない”の3 段階の評価区分を用いた。

表 2 被験者の構成

\begin{tabular}{|c|c|c|c|c|c|}
\hline \multirow{2}{*}{ 性別 } & \multicolumn{4}{|c|}{ 年路 } & \multirow{2}{*}{ 小計 } \\
\hline & 20 代 & 30 代 & 40 代 & 50 代 & \\
\hline 男性 & 7 & 3 & 11 & 3 & 24 \\
\hline 女性 & 8 & 1 & - & - & 9 \\
\hline 小計 & 15 & 4 & 11 & 3 & 33 \\
\hline
\end{tabular}

一 : 該当する被験者がいないことを表す。

\section{3. 実験結果}

\section{1 刺做振助の再現性}

図 4 は、“継続時間 10 秒、目標振幅 $2.5 \mathrm{~cm} / \mathrm{sec}^{2}$. 正弦波” の振動台上 で再現された最大加速度の分布を表し、図 5 は、継続時間 10 秒正弦波 の振動台上で再現された最大加速度と目標最大加速度の関係を表し ている。また、図 6 は、 $5 \mathrm{~Hz}$ 刺激振動各々の振動台上で再現された最 大加速度の分布を表している。

なお、図 5、図6 中の丸印は、各刺激振動の最大加速度の平均值をあら わしており、実線で示した範囲は標準偏差 $( \pm \sigma)$ を表わしている。

これらの図に見られるように、振動台で再現された上下振動の最大 加速度之目標最大加速度の差は、平均値で $\left.\pm 5 \%\left( \pm 0.1 \sim 0.2 \mathrm{~cm} / \mathrm{sec}^{2}\right)^{2}\right)$ 以 内であり、また、漂準偏差も $0.1 \sim 0.2 \mathrm{~cm} / \mathrm{sec}^{2}$ 程度とばらつきも少ない。

これてらの実験結果から、有意な振幅の差を持って、ほぼ目標通りの刺 激振動を被験者に与えることができたものと判断される。

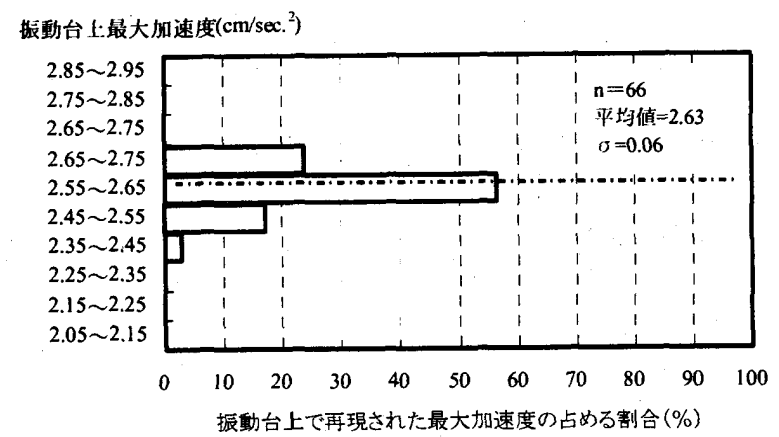

振動台上最大加速线 $\left(\mathrm{cm} / \mathrm{sec}^{2}\right)$

(a) $5 \mathrm{~Hz}$

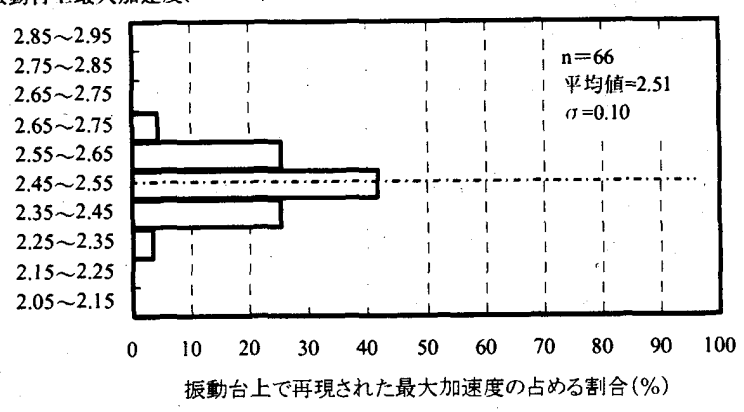

(b) $7.5 \mathrm{~Hz}$

図 4 継続時間 10 秒,目標振幅 $2.5 \mathrm{~cm} / \mathrm{sec}^{2}$ 正弦波の振動台上 で再現された最大加速度の分布

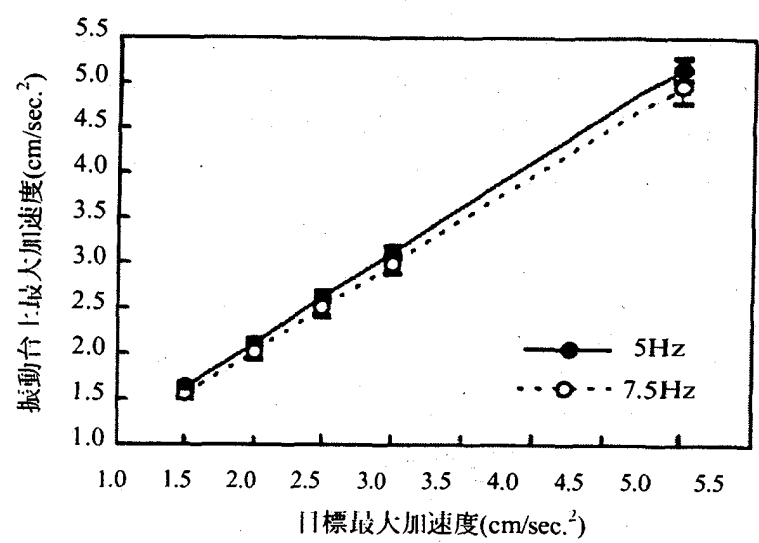

图 5 振動台上で再垷された最大加速度と月標加速度の関係 （継続時間 10 秒正弦波）

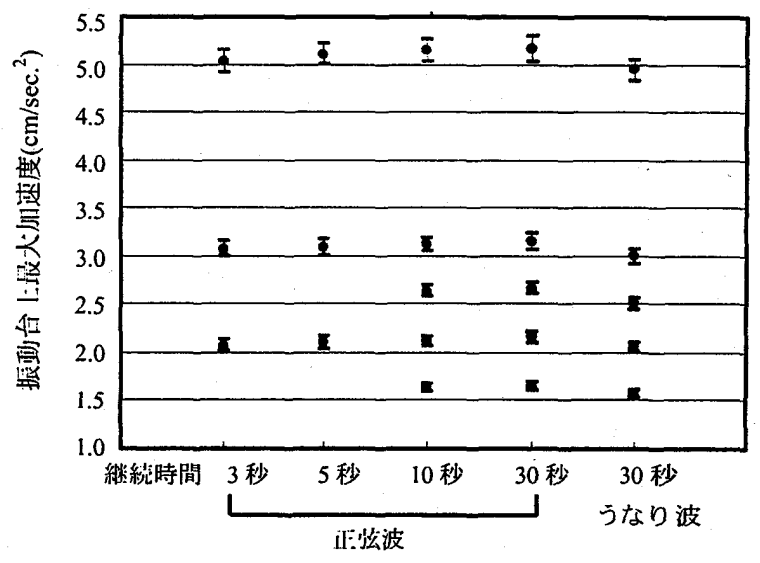

図 6 振動台上で再現されてた最大加速度の分布例（5Hz）

\section{2 振動感覚、不快度評価に関する実験結果と考察}

実験デー夕処理においては、感覚評価。不快度（居住性能）評価の傾 向を統計的に分析するために表 3 に示す数量化を行ない、最大加速度、 継続時間との関係を分析·考察する。

表 3 感覚評価、不快度評価の数量化表現

\begin{tabular}{|c|c|c|}
\hline スコア & 感覚評価 & 不快度評価 \\
\hline 1 & 感じない & 不快でない \\
\hline 2 & 少し感じる & どちらとも言えない \\
\hline 3 & よく感じる & 不快である \\
\hline 4 & 強く感じる & \\
\hline
\end{tabular}

\section{2.1 継続時間之振動感覚評価との関係}

図 7,8 に、刺激振動数毎の最大加速度と振動感覚評価の関係を示す。 図中の縦軸は数量化表現した振動感覚評価、横軸は各刺激振動の平均 最大加速度を表している。また、図中○印に、各刺激振動に対する振 動感覚評価の平均を示し、参考として縦棒の幅に母平均の 95\%信頼区 間（推定結果）を示した。

これらの図に見られるように、振動感覚評価は最大加速度との相関 が高い。また、継続時間の異なる正弦波を比較すると、継続時間が長 くなるに従い、振動感覚評価は大きくなる。継続時間 30 秒正弦波の 振動感覚評価は、継続時間 3 秒正弦波の振動感覚評洒に対して、数量 的表現すれば 10〜20\%程度大きくなることが解かる。

また、継続時間 30 秒のうなり波と他の刺激振動を比較すると、振動 数によって若干傾向が異なるが、うなり波に対する振動感覚評価は、 同レベルの最大加速度を持つ継続時間 30 秒正弦波の振動感覚評価に 比べ、10〜20\%程度小さくなる傾向にある。 
また、図 1 (b)中の破線に示すように、うなり波の振幅が最大加速度 の 7 割以上を示す継続時間が約 3 秒となるため、うなり波の振動感覚 評価は継続時間 3 秒正弦波の振動感覚評価と同程度となっている。
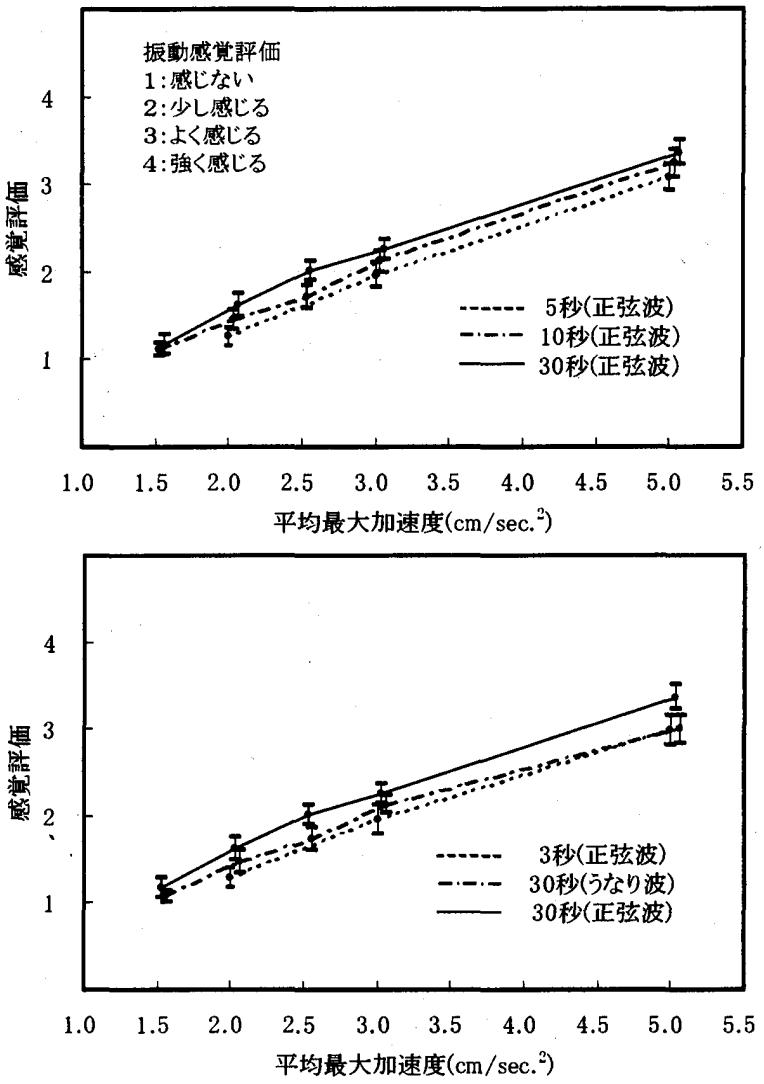

図 7 各刺激振動に対する振動感営評価結果 $(5 \mathrm{~Hz})$
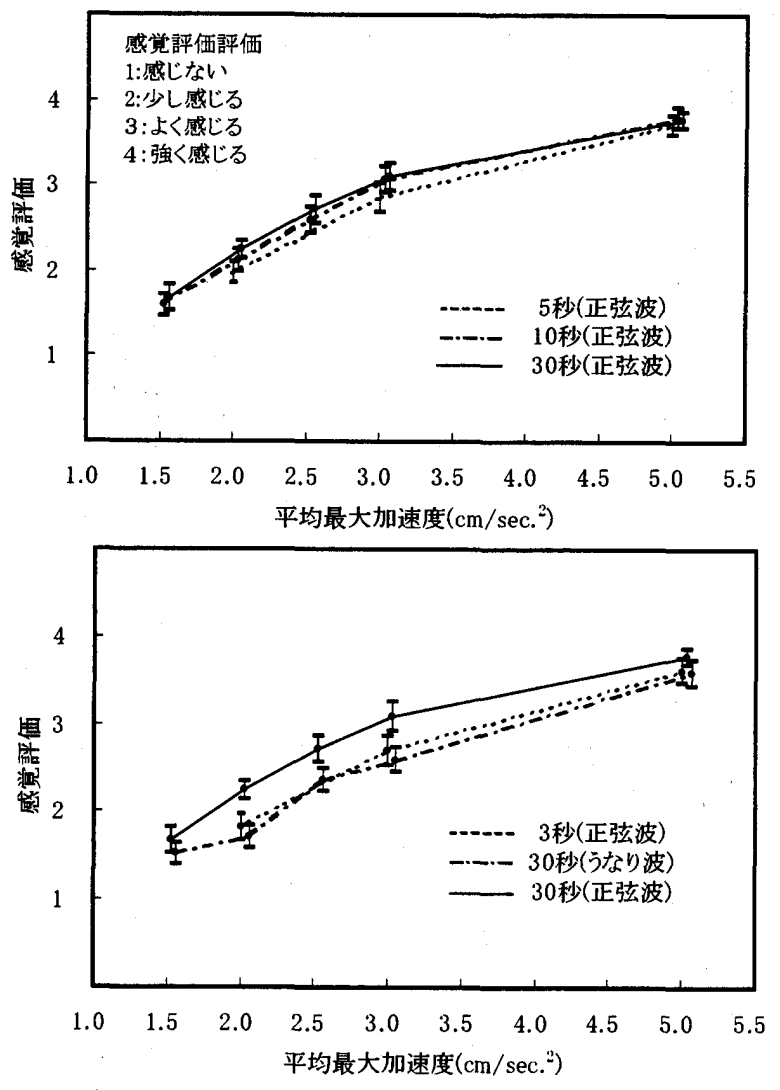

図 8 各刺激振動に対する振動感覚評価結果 $(7.5 \mathrm{~Hz})$
表 4 は、学会旧指針（1991）に整理されたマイスターの振動感覚実 験結果と本実験における継続時間 10 秒正弦波に対する平均感営評価 の対応を示したものである。

本実呀結果における振動感覚評価結果は、 $5 \mathrm{~Hz}$ に比べ $7.5 \mathrm{~Hz}$ の方がや や大きな感覚評価となっているが、、イスターの振動感覚曲楾にほぼ 対応した実験結果が得られているものと判断される。

表 4 感覚評価に関する本実験結果と既往の実験結果 7の対応

\begin{tabular}{|c|c|c|c|c|}
\hline \multicolumn{2}{|c|}{ 最大 } & $1.5 \mathrm{~cm} / \mathrm{sec}^{2}$ & $3 \mathrm{~cm} / \mathrm{sec}^{2}$ & \\
\hline \multirow{2}{*}{\multicolumn{2}{|c|}{$\begin{array}{l}\text { マイスターの } \\
\text { 振動感覚曲線 }\end{array}$}} & 「ようやく & 「ようやく感じ & 「よく感じる」 \\
\hline & & る」の下限領域 & る」の中間領域 & の下限領域 \\
\hline \multirow{2}{*}{$\begin{array}{l}\text { 実 } \\
\text { 験 } \\
\text { 結 } \\
\text { 果 }\end{array}$} & $5 \mathrm{~Hz}$ & $\begin{array}{c}\text { 「感じない」 } \\
\text { 領域 }\end{array}$ & $\begin{array}{c}\text { [少し感じる] } \\
\text { の中間領域 }\end{array}$ & $\begin{array}{l}\text { 「よ<感 } \\
\text { の中間 }\end{array}$ \\
\hline & $7.5 \mathrm{~Hz}$ & $\begin{array}{c}\text { 「感じない」と } \\
\text { 「少し感じる」 } \\
\text { の境界領域 }\end{array}$ & $\begin{array}{c}\text { 「少し感じる」 } \\
\text { とよく感じ } \\
\text { る」境界領域 }\end{array}$ & $\begin{array}{l}\text { 「よく感じる」 } \\
\text { と強く感じ } \\
\text { る」の境界領域 }\end{array}$ \\
\hline
\end{tabular}

\section{2.2 継続時間と不快度評洒との間係}

図 9,10に、刺激振動毎の平均最大加速度と不快度評価の関係を示す。 図中の縦軸は数量化表現した不快度評価、横軸は各刺激振動の平均最 大加速度を表している。また、図中○印に各刺激振動に対する不快度 評価の平均を示し、参考として絴棒の幅に母平均の 95\%信頼区間（推 定結果)を示した。

不快度評価は振動感覚評価と同様に、最大加速度の增加とともに高 くなる。また、継続時間の異なる正弦波を比較すると、継続時間が長 くなるに従い、不快度評価は高くなる。継続時間 30 秒正弦波の不快 度評価は、継続時間 3 秒正弦波の不快度評価に対して、数量的表現す れば 20〜30\%程度高くなることが解る。

また、継続時間 30 秒のうなり波と他の刺激振動を比較すると、振動 数によって若干傾向が異なるが、うなり波に対する不快度評価は、同 レベルの最大加速度を持つ継続時間 30 秒正弦波の不快度評価に比べ 小さく、振動感覚評価がほぼ等しい継続時間 3 秒正弦波、あるいは、 継続時間 5 秒正弦波よりも不快度評価が高くなっている。

\section{3 継続時間が振動感喾, 不快度評価に与える影留}

図 11,12 は、最大加速度 $5 \mathrm{~cm} / \mathrm{sec}^{2}$ の各刺激振動に対する振動感覚評 価、不快度評価の割合を示したものである。各図中の横軸は、被験者 が答えた振動感覚評価,不快度評価を表し、綎軸は各評価を下した回答 数の割合（各評価を下した回答数/全被験者の回答数）を百分率で表し たものである。

これらの図から、正弦波の継続時間が振動感覚評価に与える影響よ りも、不快度評価に与える影響の方が相対的に大きいことが良く解る。 継続時間 3 秒の場合は「不快である」と答える割合が $50 \%$ 程度に留 まるが、継続時間が長くなるに従い「不快である」と答える割合が急 激に増加し、継続時間 30 秒では 80〜90\%に達する。また、うなり波の 振動感覚評価は、継続時間 3 秒正弦波のそれとほぼ等しいが、不快度 評価は、継続時間 10 秒正弦波のそれてとほぼ等しい結果となっている。

図 13,14 は、最大加速度 $2 \mathrm{~cm} / \mathrm{sec}^{2}$ および $3 \mathrm{~cm} / \mathrm{sec}^{2}$ の $7.5 \mathrm{~Hz}$ 各刺澈振 動に対する振動感覚評価、不快度評価の割合を示したものである。 正弦波の継続時間が、振動感覚評価に与える影響よりも、不快度評価 に与える影響の方が相対的に大きくなることは、最大加速度 $5 \mathrm{~cm} / \mathrm{sec}^{2}$ と同様な結果である。 

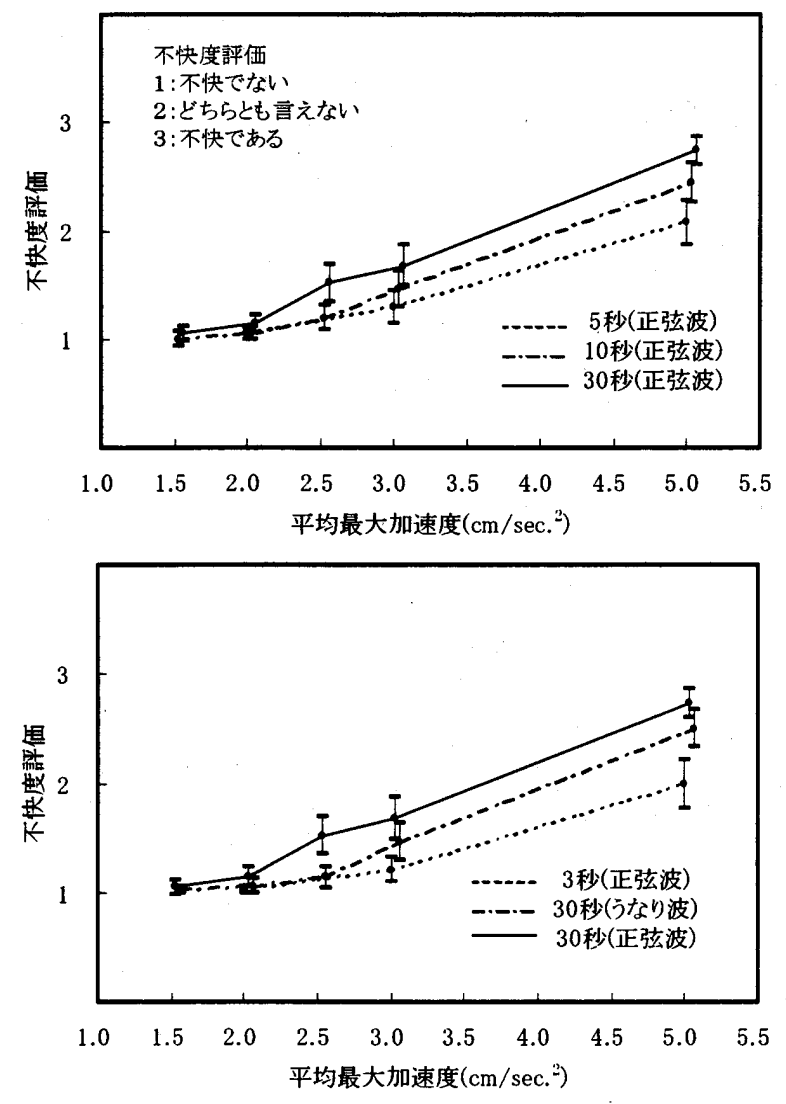

図 9 各刺激振動に対する不快度評価結果 $(5 \mathrm{~Hz})$

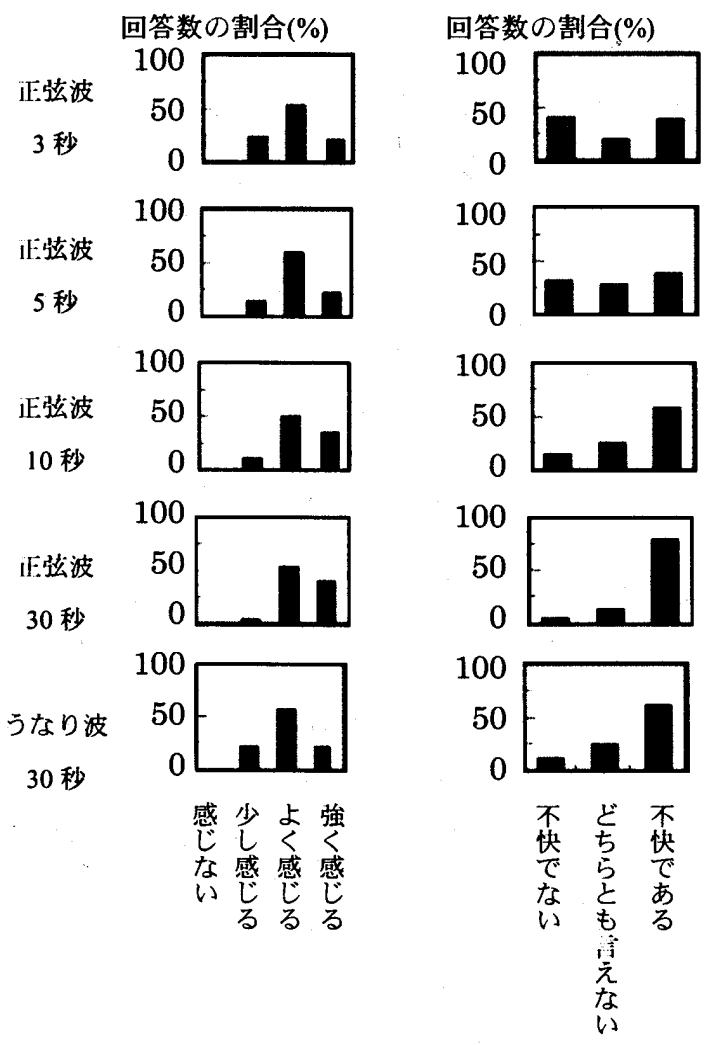

図 $115 \mathrm{~Hz}$ 最大加速度 $5 \mathrm{~cm} / \mathrm{sec}^{2}$ の振動感覚, 不快度評価
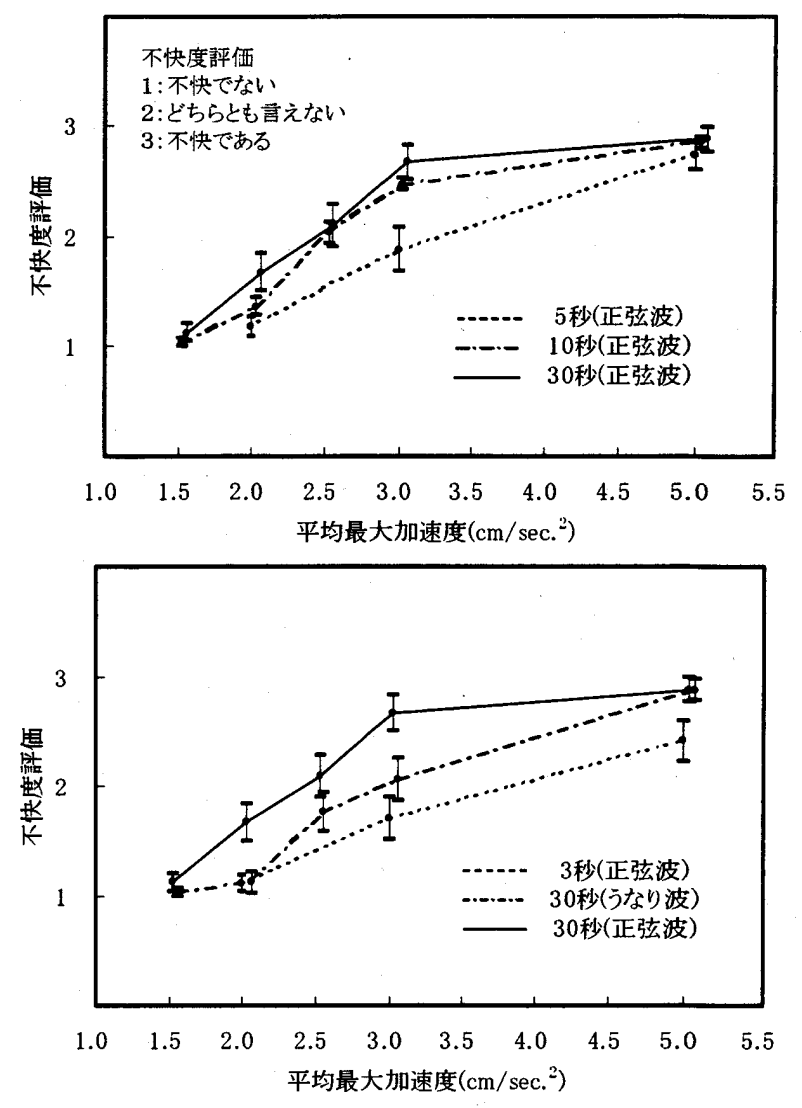

図 10 各刺激振動に対する不快度評価結果 $(7.5 \mathrm{~Hz})$

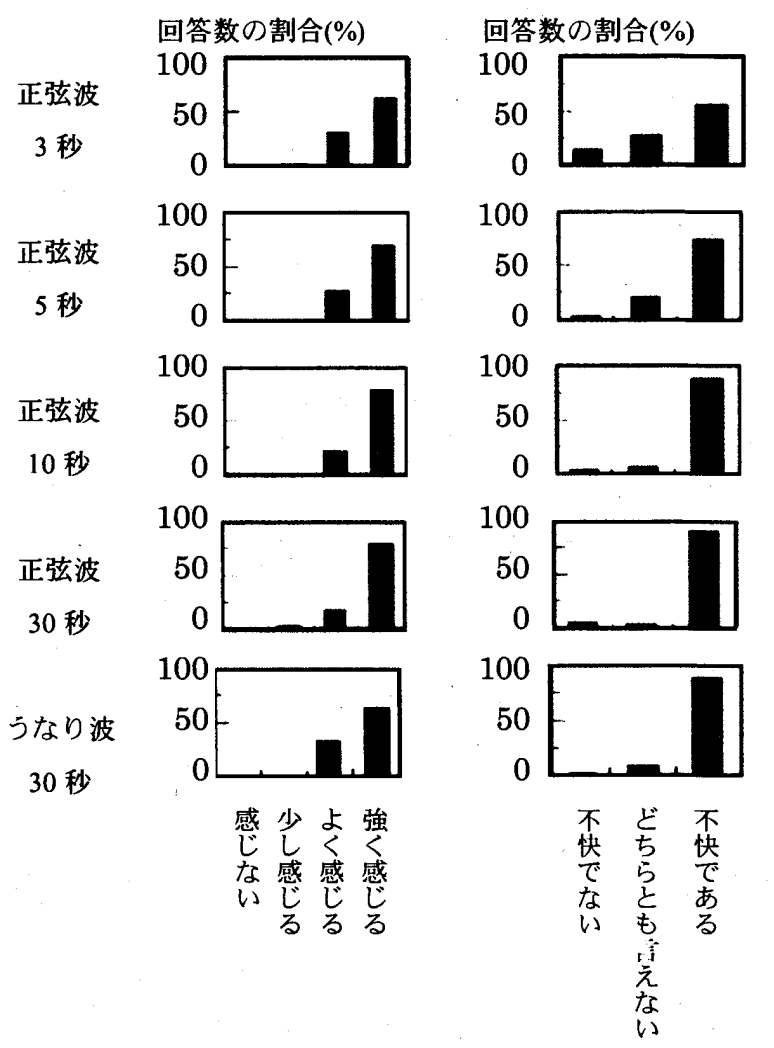

図 $127.5 \mathrm{~Hz}$ 最大加速度 $5 \mathrm{~cm} / \mathrm{sec}^{2}$ の振動感覚, 不快度評価 


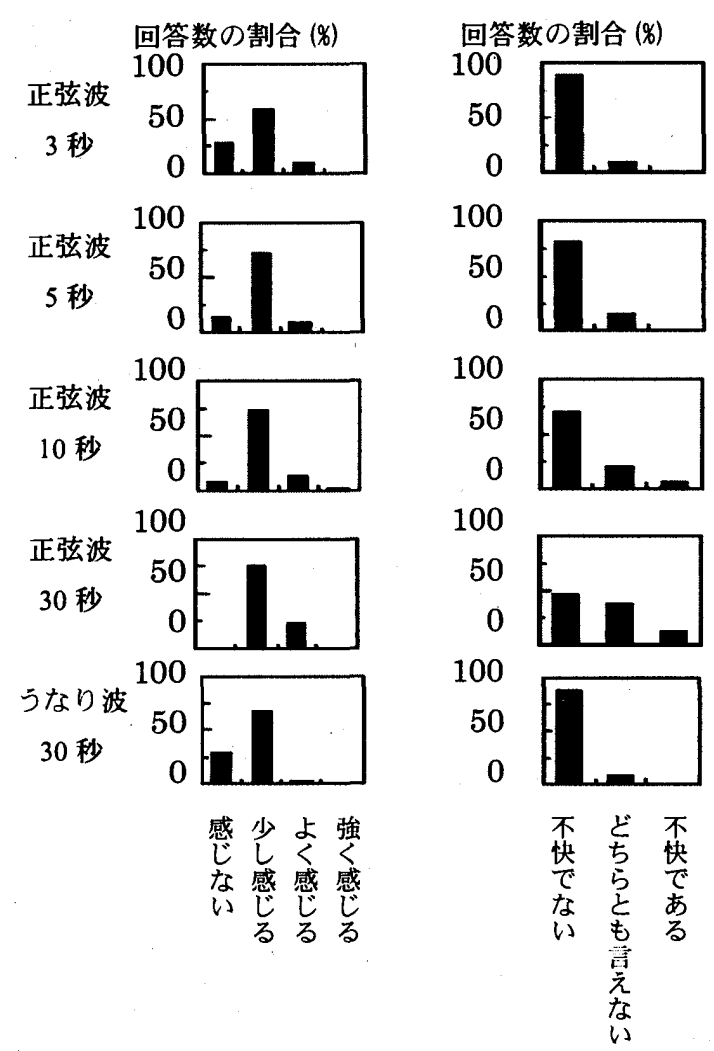

図 $137.5 \mathrm{~Hz}$ 最大加速度 $2 \mathrm{~cm} / \mathrm{sec}^{2}$ の振動感覚, 不快度評価

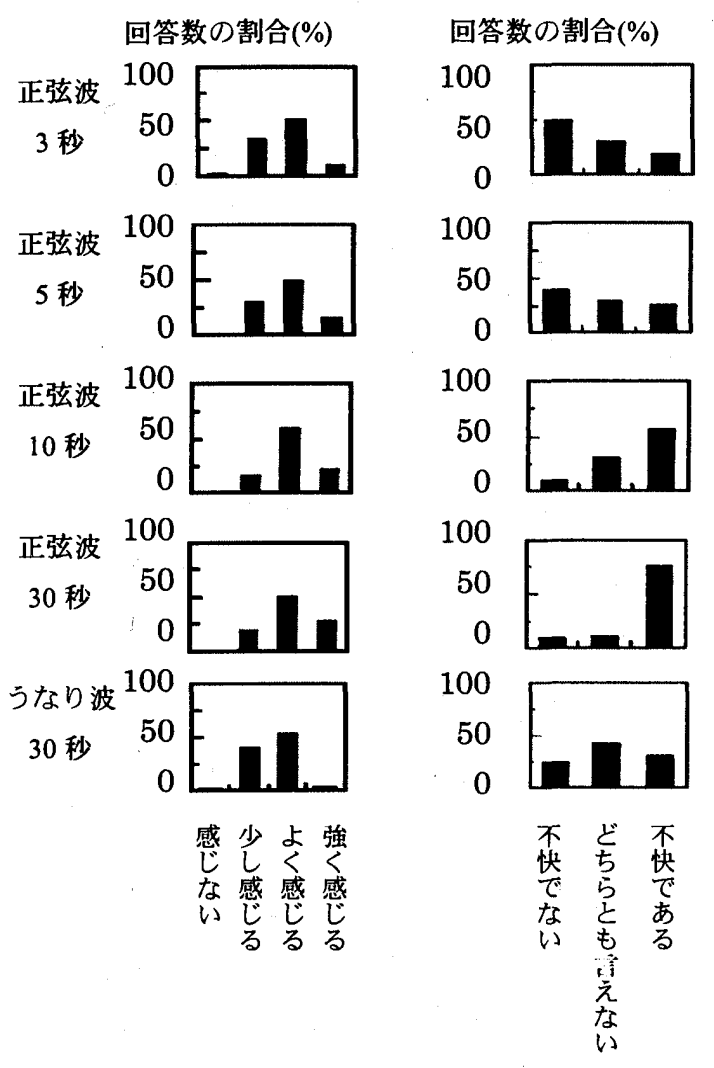

図 $147.5 \mathrm{~Hz}$ 最大加速度 $3 \mathrm{~cm} / \mathrm{sec}^{2}$ の振動感営, 不快度評佂
また、うなり波の振動感覚評価は、継続時間 3 秒正弦波の振動感覚 評価とほほ等しいことは、最大加速度 $5 \mathrm{~cm} / \mathrm{sec}^{2}$ と同様な結果であるが、 不快度評価の結果は異なる。

最大加速度 $2 \mathrm{~cm} / \mathrm{sec}^{2}$ では、 弦波の不快度評価とほぼ等しいが、最大加速度 $3 \mathrm{~cm} / \mathrm{sec}^{2}$ では、うなり 波の不快度評価は、継続時間 5 秒正弦波の不快度評価に似通っている。 この不快度評価の差については、うなり波の場合、最大加速度が小 さくなるに従い振動を感じている継続時間も徐々に短くなることが、 不快度評価に影響を与えているものと考えられる。

以上の実験結果から、林振動を感じる人の不快度を居住性能評価の 尺度と考えると、これまで居住性能評価の主軸として考えられてきた 知覚あるいは振動感覚評価に、振動の継続時間を評価軸に加えるとと もに、うなりの影響を考虑することが必要である。

以下においては、限られた実験データであるが、步行振動に比べ、 継続時間の長い 10〜30秒の振動を取り扱う場合に、継続時間、うなり の影響を考慮して、設計月標となる最大加速度をどの程度低減し、再 設定する必要があるかについての検討・武算を行なう。

こうした検討・試算を行なう主旨は、以下の 2 点である。

- 学会旧指針（1991）制定後 15 年以上が経過しているが、本指針が 活用されてきた主な設計問題は、大スパン床構造体の歩行振動であ る。構造設計者は自身が設計した建物を介して、歩行振動のような 数秒間の振動の大きさ,不快度を経験的に判断できる。しかし、本実 験が取り扱つたような継続時間 10〜30 秒の振動を構造設計者は体 感した経験がなく、判断できないのが実情である。この点が、筆者 らが遭遇したクレーム事例の設計上の問題点であった。
•また、継続時間 10〜30 秒の振動も建物内で発生頻度の高い歩行振 動とのバランスを考え、設計目標值を設定するのが合理的である。 こうした観点から、学会旧指針（1991）, 見在活用されている学会居住 性能評価指針 ${ }^{8)}$ の性能評価曲線上に現れない継続時間の影響を円滑に 取り込む方法として、設計目標値を低減する方法を検討する。

図 15 に「不快である」と答える確率分布と最大加速度、継続時間の 関係例を示した。図中横軸は、各刺激振動を最大加速度でさらに層別 した小データ群の平均最大加速度を表し、縦軸は各小デー夕群内で 「不快である」と評価を下した回答数の割合を表している。 また、図中○印は実験結果を表し、実線は、確率分布は最大加速度に 対して正規分布すると仮定して、最小 2 乗法によって求めた回帰曲線 を表している。これらの図に見られるように、回帰分析結果は、70〜 $80 \%$ ま゙の確率分布をよく表現している。

図 16 は、刺激振動毎に求めた回帰曲線から $10 \%, 30 \%, 50 \%$ のが振 動を受けた際「不快である」と答える最大加速度を推定した結果を表 している。「不快である」と答える確率が $50 \%$ となる最大加速度の推 定値は、歩行、小走りによる床振動を想定した継続時間 3 秒程度の振 動については、各々 $5.5 \mathrm{~cm} / \mathrm{sec}^{2}(5 \mathrm{~Hz}) 、 4.5 \mathrm{~cm} / \mathrm{sec}^{2}{ }^{2}(7.5 \mathrm{~Hz})$ 程度であ り、学会旧指針(1991) V-5 (事務所の一般的なよりどころ)にほぼ相 当している。これに対して、継続時間 30 秒については $5 \mathrm{~Hz}$ では $4 \mathrm{~cm} / \mathrm{sec}^{2}{ }^{2}$ 程度、7.5Hz では、 $2.5 \mathrm{~cm} / \mathrm{sec} .^{2}$ 程度となり、30 50\%程度小さな 值となっている。

上記の試算結果から、継続時間 10〜30秒の振動を取り扱う場合には、 歩行振動等に適用してきた設計月標値に、30〜 50\%程度の低減率を乗 じて再設定する必要があるものと考えられる。 

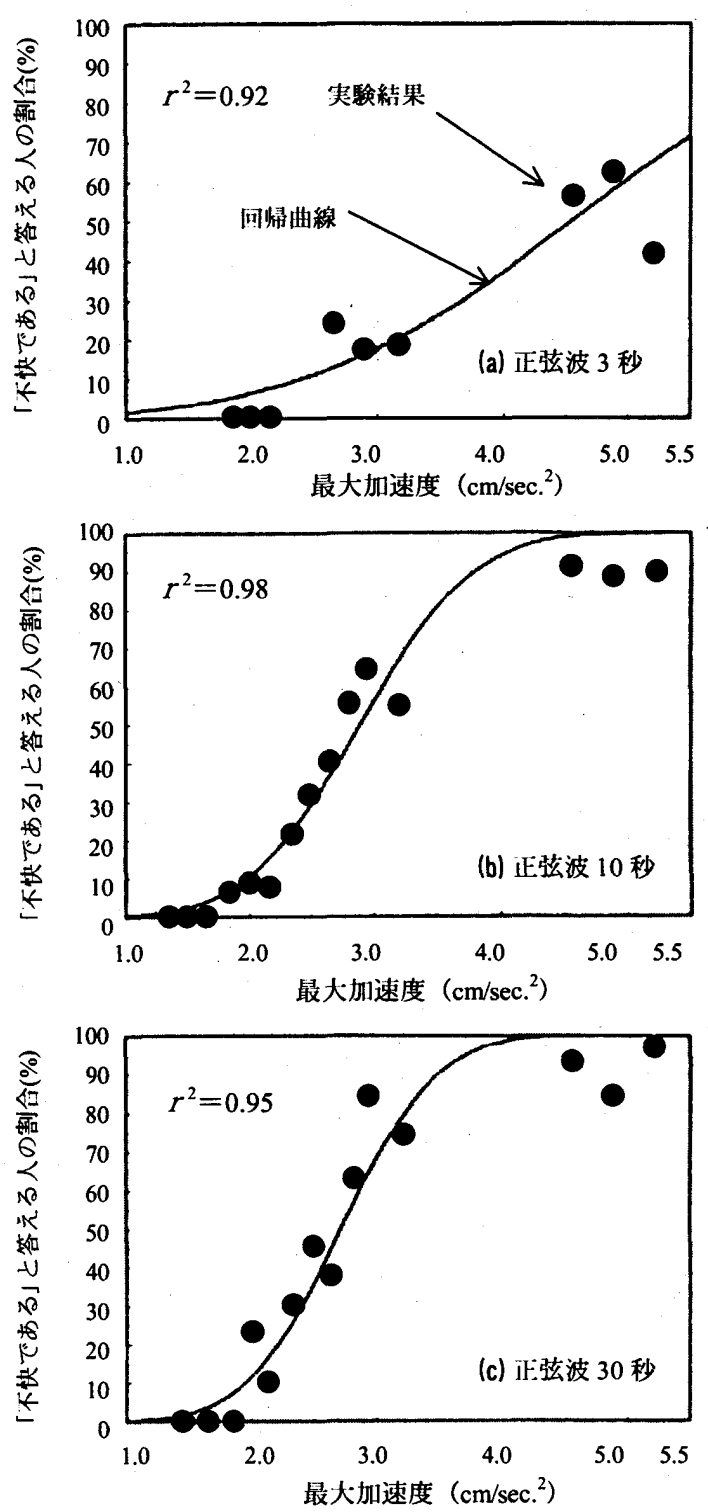

图 15 正弦波振動に対して「不快である」と答えた割合と 回帰曲線例 $(7.5 \mathrm{~Hz})$

\section{4. まとめ}

上記の実験、考察結果の要旨は、以下の通りである。

1）朱振動の継続時間が振動感覚評価に与える影響よりも、床振動の 継続時間が不快度評価に与える影響の方が、相対的に大きいこと を示した。また、床振動を感じる人の不快度を居住性能評価の尺 度と考えると、これまで居住性能評価の主軸として考えられてき た知覚あるいは振動感覚評洒に加え、振動の継綂時間、うなりの 影響を考慮することが必要である事を明らかにした。

2)【建築物の振動に関する居住性能評価指針・同解説」7》,8〕の居住性 能評価曲線上に現れない床振動の継続時間の影響を円滑に取り 込む方法として、設計月標值を低減する方法を検討した。また、 限られた実験データであるが、実験結果から振動の継続時間、う なりの影響を考虑した低減率を試算した。

なお、実験を実施したうなり波のバターンは1ケースのみであり、そ の影響評価については（その2）において報告する予定である。

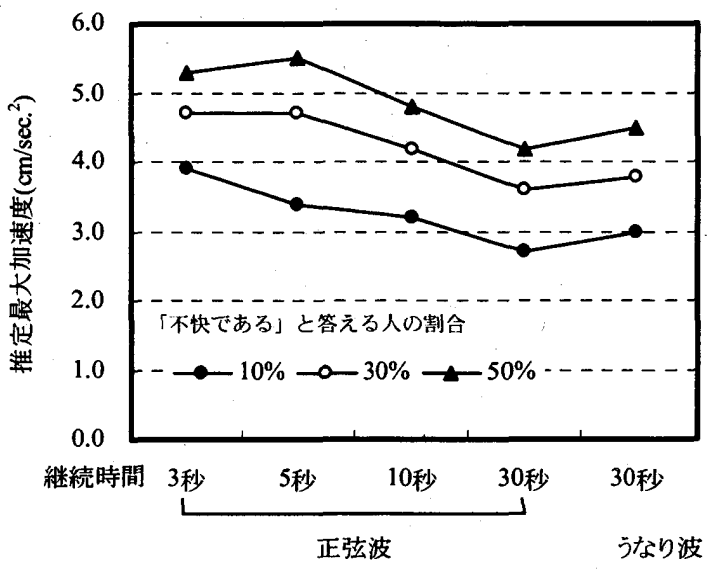

(a) $5 \mathrm{~Hz}$

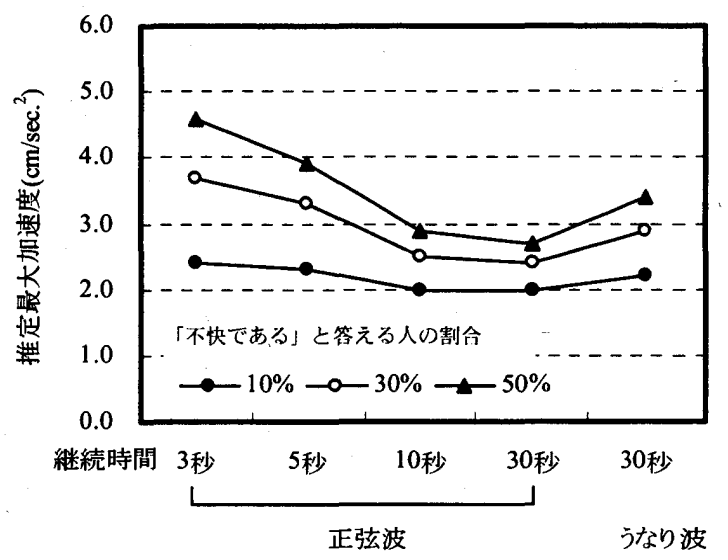

(b) $7.5 \mathrm{~Hz}$

図 16 「不快である」と答える最大加速度の推定結果

参考文献

1）高橋良典,村井信義,“床構造の隇衰性能に関する実験的研究”，日 本建築学会構造系論文報告集,第 387 号”,pp.89-96,1988.5

2）高橋良典,片山和喜,吉岡宏和,今沢民雄,“林構造体の減衰性能に関 する実験的研究(その 2) ”，日本建築学会構造系論文集,第 507 号,pp.61-67,1998.5

3）高橋良典,片山和喜,吉岡宏和,今沢民雄,村井信義, “床構造体の减 衰性能に関する実験的研究(その 3)”，日本建筑学会構造系論文 集，第 529 号,pp.81-88, 2000.3

4）三輪俊輔，“振動の感覚と評価”，音響技術 no.2, pp.23-31, 1972.7

5）高橋良典,吉岡宏和,田中利幸, 瀬川輝夫他, “床振動の継続時間と 振動感覚評価に関する実験(その 1 )実験概要(その 2 )実験結果”， 日本建築学会大会学術講演梗概集,D-1 分冊,pp.291-294, 1997.9

6）石川孝重,野田千津子, “鉛直振動に対する知覚閾および感覚評価 に関する実験的研究”, 日本建築学会環境系論文報告集,第 588 号, pp. $9-14,2005.2$

7）日本建築学会 : 建築物の振動に関する居住性能評価指針・同解説 （1991 制定）、丸善、1991

8）日本建築学会 : 建築物の振動に関する居住性能評価指針・同解説 （2004 改定）、丸善, 2004

9）（社)日本音響材料協会，“騒音振動対策ハンドブック”，技報堂出 版,1982 年 1 月 